\section{An Everlasting Gospel}

\author{
G.E. Bentley, Jr.:
}

The Stranger from Paradise:

A Biography of William Blake

(Yale University Press, 2001)

G.E. Bentley, emeritus professor of English at the University of Toronto has long established his name as an eminent Blake scholar. Besides numerous other publications, his Blake Records (1969) and the subsequent Blake Records Supplement (1988) - in which he traces the theretofore known documents concerning Blake - have become indispensable for researchers. The long-awaited new and updated edition of Blake Records is scheduled to be published in November 2002 .

In The Stranger from Paradise Bentley has set out to portray William Blake the human being, very much like ourselves. The Blake we get to know from this new biography is not the eccentric madman as he was most frequently labelled by his contemporaries, nor is he the mystical visionary whom posterity regarded with a distinct awe, but much rather an artist put in the context of his own age.

The biography encompasses virtually everything that can be known of Blake's life. Starting with his baptism at St James's, this generously docu- mented account traces Blake's carrier from the house of his dissenter parents to his "removing from one room to another" (as he considered death). The biography spans over a century, from 1720 to 1831; it records not only Blake's life but also investigates his family background, as well as the years after Blake's death; how his wife, his "Shadow of Delight," as Blake called her, handled his legacy and how she coped with Blake's absence. As we read the pages of this affectionately written account, we learn about Blake's lifelong companion, Catherine; tribute is given to the patrons, without whose support some outstanding works of art would not have been conceived. It is especially important to note that while we like to think of Blake as a neglected genius who lived in pathetic poverty and obscurity, Bentley's biography formulates a more sophisticated vision: we can follow Blake from his five-room flat of his relatively profitable years to the heartrending conditions of his late years. What is exemplary in Blake's life is the fact that he could maintain his essential humanity; although in his poems he may be eccentric and mystical in his ways he was just a person who was able to retain his confidence in the divine vision, despite his frustrations with this-worldly matters. 
That he was not living completely in his visionary universe is eloquently proved by the fact that he was a keen theatre-goer. Nor was he always living in total obscurity. Bentley's documents show Blake among prominent contemporaries, even if he did not actively look for the company of well-known (or well-to-do) people. Towards the end of his life Blake lost his patrons but gained some dedicated friends. His young admirers, the "Ancients" (hardly out of their teens) looked upon him as their revered Master (the "Interpreter"). When Blake died, young George Richmond, a future Royal Academician, closed his eyes "to keep vision in." This group of young artists handled on their knowledge of Blake to Alexander Gilchrist, Charles Algernon Swinburne and William Michael Rossetti and initiated a Blake worship.

What is especially impressive about Bentley's biography is not only that it conveys very interesting new materials but also that what has been well known and taken for granted is now reconsidered in the light of new findings. Thus some of the canonical accounts of Gilchrist (a platform from which Blake's twentiethcentury reputation was launched) are questioned and collated with other sources to get a more reliable picture of the artist. In the Addenda we are given extracts from John Clark Strange's abandoned biography (hitherto unknown) to round out Gilchrist's vastly influential work. Similarly, previously published biographical accounts are commented upon and updated.

Blake enjoyed a very slight reputation in his lifetime as a poet. He was trained, and indeed earned his living as a visual artist, as Bentley illustrates. Hence the biography does not concentrate on Blake's poetical works, no analysis is given of the Poetical Sketches, the Songs or the Prophetic Books as poems; instead everything is disclosed about them as marketable products or books as artefacts: their method and mode of publication, how Blake engraved or illustrated them, how much he earned from these works (when applicable); in short, we find the sort of information that we are not likely to come across in any monographs on Blake. Although all the remarks and comments of the outstanding contemporaries (Wordsworth, Coleridge, Southey, Hazlitt, to mention just a few) are carefully noted, the book is more of a masterfully documented biography of an artist (visual, above all) than an interpretation of the poetic credo of the idiosyncratic visionary. The Stranger for Paradise was not 
conceived to supersede Erdman, Frye, Raine, Damon, Bloom or the other canonical Blake scholars but to complement them. What is missing from the hitherto published monographs, however, is provided here: a comprehensive mapping of the life of Blake as a craftsman. Bentley gives a minutely detailed rendering of his everyday life as an apprentice, then engraver and painter, discussing not only the great influences, artworks and projects (even those aborted) but the seemingly more trivial matters of his financial and housing conditions, his studio and tools of trade, or even the china he drank his tea from. While providing an all-encompassing picture of Blake, Bentley delineates contemporary London with its streets, beliefs, people; we get a compelling glimpse of its everyday commercial, intellectual and artistic life.

Of the many novel aspects in the biography, suffice it to mention just a few that can help us formulate a new image of Blake. It is customary in Blake scholarship to relate him to a wide variety of traditions; Kathleen Raine provides an exhaustive study. of the poet's Neo-Platonic ideas, while Harold Bloom's Blake is a Christian visionary. Bentley points to the importance of the Dissenting tradition in Blake's family and asserts that the essence of the credo of his Enthusiasm is to be traced back to this family inheritance. While substantiating this claim he tells us a great deal about the impressive erudition of these Dissenting circles. It is interesting to point out that according to Bentley's research, there seems to be not enough evidence to support E.P. Thompson's assertion that Blake had close links with the Muggletonians, an idea he formulated in his highly acclaimed book, Witness against the Beast.

It is fascinating to note that while most commonly Blake is thought of as an exalted mystic visionary, Bentley shows a new side of him as a teacher. Blake taught not only his wife and brother (which is wellknown) but also in the 1790 s "he taught Drawing \& was engaged for that purpose by some families of high rank." It is quite likely that he taught at Mrs Butts's boarding school for young ladies, and probably far more of his "time and income were involved in teaching than we have direct evidence for."

Bentley also argues that Blake, pressed by financial needs was reduced to engaging in commercial designs, "rather surprisingly, one of his most ambitious commercial plates was a folio advertisement designed and engraved by Blake for Moore \& Co.'s 
carpets (1797), showing a palatial carpet factory scattered with royal emblems in enough detail to suggest that Blake had actually visited the factory." Furthermore, the man who created the magnificent Illuminated Books and Prophecies, engraved the ambitious Canterbury Pilgrims and made the remarkable designs to Young and Gray, was bound to humble copywork. Upon Flaxman's persuasion he was employed by the famous pottery manufacturer Josiah Wedgwood to engrave for the firm's catalogue.

"Wedgwood would send to Blake the soup terrine or bedpan to be represented, and Blake would draw it and send the drawing to Wedgwood, who would despatch another piece of pottery. When all the drawings were completed, Wedgwood directed how they should be arranged on the copperplates."

In The Stranger from Paradise, this beautifully illustrated biography of Blake, Bentley successfully makes a case against the common mistake of Blake's contemporaries who regard him as a decided madman, as well as against the mistake of our present day to consider him as a religious mystic, who "is always in Paradise."

It is time, asserts Bentley," to let the unmediated evidence for Blake's life speak for itself, purged as far as possible of the myths that have been industriously spun around him." Indeed, as any reader of the book will justify, Blake's "life is more that an illumination of his own poetry and designs. It bears the shape of great art itself. From his youthful vaulting ambitions in painting, engraving, poetry, and music, through his mature flirtation with Goddess Fortune, to his joyful return to the vision and confidence of his youth, Blake's life provides a pattern to noble self-sacrifice and wise selfunderstanding which inspired admiration and love in his generation and in ours."

Despite some unappreciative voices (as in The Observer 13 May 2001 or Daily Telegraph 19 May 2001), The Stranger from Paradise was very favourably received. The biography sold out so rapidly that a new (paperback) edition is to be published soon. DÓRA JANZER CSIKÓS 